\title{
The Path of Improving the Quality of College Teachers
}

\author{
Minghui Wang \\ Chang Chun University of Technology, Changchun, China \\ wmh@ccut.edu.cn
}

Keywords: Colleges and universities, teacher, quality.

\begin{abstract}
By sorting out the basic connotation of teachers' quality in Colleges and universities, from the aspects of morality, knowledge, ability, and demonstrates the quality requirements of teachers in Colleges and universities, establish advanced educational concepts, advocating good ethics, studying excellent business ability, cultivate healthy mental quality four aspects from the proposed ways to improve the teachers' quality in Colleges and universities.
\end{abstract}

\section{Introduction}

Universities should take the training of talents as the center, carry out teaching, scientific research and social services, to ensure the quality of teaching and education to meet the standards of the state [1]. With the rapid development of higher education, especially the teaching reform and the talent training mode transformation new mission entrusted by the building of the contingent of teachers colleges and universities, on the quality of teachers proposed new and higher requirements, improve the quality of university teachers is doing a good job in the basic guarantee for the education and teaching in Colleges and universities.

\section{The Basic Connotation of The Quality of Teachers in Colleges and Universities}

Teachers' quality is stable teachers professional quality, is formed through science and education and self - improvement has certain characteristics of the times thought, knowledge, ability, and the characteristics of body and mind, and vocational training; teachers to fulfill their duties and necessary in accomplishing the task of education and teaching of literacy and literacy organic combination together. The quality of teachers, which is the sum of the psychological quality of teachers in teaching activities, determines the effect of education and teaching, and has a direct and significant impact on the physical and psychological development of the students. Teachers in Colleges and universities is facing a transformation from quantity guarantee to quality improvement, to adapt to the present practice of the higher education, teachers' quality should include four aspects: Science and cultural quality, professional quality, occupation moral quality, physical and psychological quality, etc.

\section{The Quality Requirements of College Teachers}

\subsection{Quality Requirements of Teachers' Morality.}

Treat the moral of education. Teachers in Colleges and universities should do their own work with the teaching and training of talents. Love the people's education, it is not only an important symbol of the overall high reputation of college teachers, but also a strong motivation for each teacher to do a good job, is a teacher must have the most basic professional ethics. Not afraid of hard, willing to sacrifice, this is the special requirements of the society for college teachers in the dedication and labor attitude. Efforts to forge ahead and create a first-class job, this is a college teacher in education should follow the important moral principles.

Treat the moral of education object. Loving and caring for students is an important principle of teaching students and a great educational power. It is the core of the professional ethics of college teachers. Respect and trust the students, is an important prerequisite for good education. To treat the students, to establish a new type of relationship between teachers and students, and to maintain a 
tension between teachers and students. Strict requirements for each student, is an important part of the teacher's love.

Treat the morality of peers. Respect other teachers' personality and reputation, support and cooperate with other teacher's work, is a teacher must follow the code of conduct.

\subsection{Knowledge Quality Requirements.}

Excellent professional knowledge. Professional knowledge is the premise of teaching, there is no rich, excellent professional knowledge, teaching cannot be carried out or the teaching effect is not ideal.

Good comprehensive cultural quality. Teaching is a complex process, using a variety of knowledge and information to enhance the teaching of art, appreciation and attraction. College teachers have a good comprehensive quality, cultural and artistic accomplishment is very important to the education and teaching.

Continue to learn the requirements of knowledge, ability and habits. Know what is necessary to master the knowledge, from where to get and how to get these knowledge, and how to use these knowledge.

\subsection{Quality Requirements in Terms of Competence.}

Teaching design ability. Analysis of students to determine the learning style of the students, to further determine the learning objectives. An excellent teacher should pay attention to the teaching of the students' scientific spirit, innovative spirit and hard struggle spirit.

Teaching ability. As far as possible to create and form their own distinctive teaching style, to master a variety of teaching skills, to be creative teaching ability, have excellent teaching basic skills.

Self-study ability. Establish a lifelong learning idea, can in a certain period of time, learn more knowledge, to obtain more useful information.

\section{Ways to Improve the Quality of College Teachers}

\subsection{Set up the Advanced Education Idea.}

To set up scientific quality view. Students are the foundation of running a school, is a school brand, to establish the concept of student oriented, and constantly strengthen quality awareness, brand awareness and awareness of education, adhere to the interests of students first.

To set up the scientific concept of talent development. In teaching philosophy, from imparting knowledge to pay attention to health for the change, from the simple teaching change to comprehensive education, respect students' personality and students concerned about the state, pay more attention to the students' differences, and stimulate their learning initiative and creativity.

To set up scientific teaching concept. To realize the transformation from the traditional teaching view to the modern teaching concept, to stimulate students' learning enthusiasm and initiative.

\subsection{Advocating Good Ethics.}

Establish a correct moral concept, to create a good image of teachers. Body Rikkyo, with a sincere heart to care for students, cultivate their sentiments, purify the students' mind.

To set up lofty ideals and loyalty to the education of the people. Not only to impart knowledge to students, but also to the way of thinking, outlook on life and values to the students.

To establish a strong sense of professionalism. The sense of responsibility is the primary condition to be a good teacher, and the responsibility of the teacher is from the love of the cause and the firm belief in the cause of education.

\subsection{To Delve Into the Consummate Business Ability.}

Perfect knowledge structure. Continuously enriched with subject specific knowledge and education, sociology, psychology, and to achieve the teaching objective of educational practice knowledge, has a more profound knowledge and skills.

Excellent teaching basic skills. Teaching content accurate mastery, key and difficult properly handled, structured hierarchy reflects teaching logic and expression of a vivid manifestation of the teaching art of strict standards for students with rigorous academic training and thinking, Lenovo, the creativity of the enlightenment. 
Strong practical ability. Emphasis on practice, pay attention to experience, focusing on ability training, student guidance, compound teachers as well.

\subsection{Develop a Healthy Body and Mind Quality.}

To maintain a healthy body and a good mental outlook. Have strong energy, good mood, with real love life feelings, to affect the students.

Good psychological quality. With just, caring, firm, calm, patient, self-reliance, personality, cheerful, approachable psychological quality, to shape the students a good mind and a sound personality.

Perfect healthy personality. With a noble aesthetic sentiment, in the natural, social and artistic experience in the pursuit of the United States, the United States, the United States and the United States, the United States to identify, to adapt to the needs of teaching and education.

\section{References}

[1]. Higher education law of the People's Republic of China. Information on http://www.gov.cn

[2]. Higher education law of the People’s Republic of China. Information on http://www.gov.cn 